\title{
科学者像の 変革の方向を探る
}

日本百術会議 創立50周年

人々のための科学

科学技術基本法が制定されてから5年が経過し た。この制定は、高度経济成長を達成して、世界 経済の中で重要な部分を占めるようになったこと を背景としてわが国が過ごすべき次の時代を、そ れ以上の自国の経済的繁栄のみならず、経済的影 響力の強い国として果たすべき国際貢献、環境問 題をはじめとする人類共通の困難な問題における 国際協力などにおいて、科学技術の振興を重要な 手段と位置づけて展開していくことの、いわば国 民的決意であったと言うことができる。

現実的に、その制定は基礎研究費の増大をもた らしただけでなく、研究費の配分や使途に変化を 生み、大学改革に打ける研究組織の変革と連動し て、わが国における基礎研究の状沉はかなりの程 度に改善された。もちろん、科学以外の古い制度 や慣習によって、この期間に大学の建物などはさ らに劣化が進行したり、社会に打ける研究者の雇 用が増加せず、特にポストドクトラルフェロー以 後の雇用が配慮されないことによってキャリアパ スが乱れるなどの問題を積み残してはいるが、こ れらの解決に向けた努力をわれわれも始めている のであり、困難は多いにせよ見通しがないわけで はない。困難を抱えながらも、わが国は科学技術 の社会への影響を強く認識した上で、その進展を 進めている国と考えてよい。

このような認識は世界的なものである。国際科 学会議 (ICSU) は、1999年7月の世界科学会議 (Budapest) において、科学技術の重要性を強く主 
張する宣言書を発行した。その中で、人類に豊かさ をもたらした最大の要因は科学的知識であることを 総論づけた上で、しかしそれへの平等なアクセス と、科学技術的知識の悪用ないし誤用による弊害を 十分認識した上で、科学技術研究について、科学者 と、政府、民間諸団体が認識を共有して進めるべき 活動計画を提案している。

また、80 カ国以上のアカデミーで構成されるイ ンターアカデミーパネル (IAP) では、「維持型社会 への移行」と題する国際会議を2000年に開催する。 これは日本学術会議が開催団体となり東京で開催す るのであるが、その開催趣旨は明解である。2050 年に人口は 80 億を超える。そのとき、人類の生存 にとって必要なもの、すなわち住居、食糧、健康、 環境、教育などは十分な形で供給可能であろうか。 答えは否定的である。この危機を克服するために は、科学技術の力に頼らざるを得ない。現実には、 土地、空気、水、材料、エネルギーなどの自然資 源、また資本、知識、組織などの人工資源を投入す ることによって克服するのであるから、これらを科 学技術の知識によって十分なものとして準備するこ とが必要条件である。この論旨によって会議が構成 される。そして抢そらく、土地や空気などは、古く からのあるいは新しい政治課題であり、政治的活動 領域である。すなわちここには、会議の対象は科学 技術であるが、その先に経済や政治という社会的装 置に対する勧告などの働きかけをも視野に入れると いう一面が、この国際会議に与えられている。

このように、科学の社会における位置づけは急速
に変わってきていると言って間違いないであろう。 簡単に言えば、科学が国家の所有のもとに軍事的な 力であった時代を経て、第2次大戦後に科学のため の科学の時代が到来したが、それは利用価值の高ま りとともに社会経済のための科学となり、そして 今、人々のための科学という時代が到来しつつある と言ってよいであろう。その一つの例は、最近の米 国の政策に現れてきた。米国の科学技術政策は、 Vannevar BushのScience-Endless Frontier に書 かれたように、科学は人類に無限の夢を与えるとい う立場を基本としてきた。

しかし現在、この立場は変更のきざしをみせてい る。米国議会の科学委員会委員長 Sensenbrenner Jr.によれば、新しい政策の重要な視点は、科学研究 における研究産業の役割重視、政府援助に対する十 分な説明責任、そして幼稚園から研究大学までの教 育問題であると言う。ここにも、極めて内向きへと 変換する人々のための科学という立場が、明確に見 えている。ここで人々とは、観念的な国民や一般庶 民などではなく、公共費用をどんな科学的課題に対 し投資するのかを自らの税金を背景にして考光、現 実に効果しようとする、実在する人々なのである。

\section{わが国の責務}

基礎研究が公共的費用によって行われるのは、現 代に打ける世界共通の事実である。そしてそれは、 基礎研究は市場経済の中で負担する者が国家以外に いないから、公共的費用で行われると考えることは 間違っている。それはより積極的に、基礎研究によ 
つて得られる知識は、国家、企業、その他あらゆる 機関によって占有されてはならず、人々の誰でもが 自由に接近し、利用できるものでなければならず、 したがって本来公共的費用の投入によって作られる べきもの、という意味をもっている。もちろんこれ は原則論であり、国家間の知識格差、知的財産権問 題など、現実には様々な問題を抱えてはいるが、そ れらはこの原則論を目標としながら、徐々に解決さ れつつあると考えてよいであろう。

そして、このような科学をめぐる国際的な潮流の 変化にわが国も乗っていて、例外ではない。しかも、 最初に述べた科学技術基本法のもとで基礎研究を振 興中のわが国は、研究費の縮小に悩む諸外国の中で は、基礎研究推進の主役としてますます重要な役割 を担うことになりつつある。したがって、わが国が基 礎研究を社会の中にどのように位置づけ、またその 成果を人々にどのように返済して行くのかについて、 諸外国は大きな興味をもち、注目している。そしてそ の関心は、国としての科学技術政策だけでなく、基 礎研究を実施する研究者一人ひとりの考え方にまで 及ぶのである。そこには、現代における科学者像の変 化という関心があり、しかもそれは、研究者の社会 的身分、研究機関の設置、その中での組織や管理、 研究費の配分、評価などを通じて、科学技術政策と 無関係ではない。したがって、科学技術政策から一人 の科学者まで、様々な要因は一つの社会現象として 関心がもたれる。わが国のそれは、どのような特徴を もち、またどの方向へと動いて行くのであろうか。

あえて率直に言えば、社会現象としての全体は、
極めて変化が遅いことをわが国は特徴としていると 言うべきであろう。わが国の研究機関は、大学が最大 であり、国立研究所、民間研究機関などが続く。研究 者のほとんどを雇用する大学と国立研究所を特徵づ けるのは、形骹的組織責任とも言うべき状況である。

これは、第 2 次世界大戦以後、一人ひとりの科学 者が研究の自治をもつという、勿論正しい理念を根 拠として、本来研究者個人のもつ自治と責任とは別 ものであった組織の自治を、組織を構成する個人が 奪取し、分散所有し、しかも責任だけは組織に残す という構造である。組織の責任をもつ者は、結局自 ら決定する権限の範囲、すなわち自治領域を極小化 されているから、何か起こっても責任の取りようが なく、もともと責任をとる気も起きない。したがっ て、不祥事と指摘されて社会的に紏弾されるときの み、形骸的責任をとるというものである。

例えば、日本の大学で将来を見越して環境問題や 生命、情報などの分野を独立して組織化する必要は なかったのであろうか。多くの教授たち、あるいは 学長は、それを長い間必要と考えていたのであっ た。しかし、そのことを決定することは、既存の領 域を護る学部教授会に依拠する大学の管理方式では 不可能であり、その出発は大幅に遅れてしまった。 その遅れが諸外国に比べあまりに顕著になりはじめ たとき、その指摘が社会的に広くされるようになっ たのであるが、その遅れの張本人は不明のまま誰も 責任をとろうとはしない。それは学部教授会なので あるが、そこは責任をとることはおろか、それを察知 する感受性をそもそももたない組織なのである。 


\section{日本学術会議}

科学が人々のための科学という、おそらく本来の姿 を実現しようとしているこの時期に、わが国は前述の、 科学技術政策から科学者像という社会現象をどのよ うに、また誰を主役として変革していくのか、それ を明らかにすることは重要なことである。

前述したような、科学者の多数を擁する大学の状 況は改善が進められているとはいえ、その速度は遅 く、社会現象としての科学の変革の原動力として期待 するには心許ない。あるいは、基礎研究振興の中で、 各分野でそれぞれ研究推進の主役を担わされている 大学は、科学全体の流れや科学者像の変化などに関 心を寄せる余裕はないのかも知れない。これは当然 とも言える。所属する研究者の利害を代表する大学 は、科学全体を見る目とは異なる目をもっていてよ い。すなわち、大学は研究の推進者であって舵とりする 者ではない。とすれば、この変革のコンセプトをつく る者、すなわち正しい方向へと舵とりする者が、別に いなければならないことになる。しかもその者は科 学者である。社会における民主主義の進行を歓迎し つつ、しかもそのことと関連する固有の問題が数多 く発生しつつある。そしてそれらの多くは、科学によ つて解決が可能であると信じられている。すなわち、 その可能性は科学者の手の内にある。しかし、科学の 主権は人々にあるのであって、科学者にあるわけで はなく、また権力としての国家や大資本などが、恣意 的に科学を操ることは許されないし、またできな い。ここでは多くの人々の合意に基づく政治的決定
があるときにのみ、実効をもつ行動が可能となる。

こう考えただけでも、科学者の役割の変化に気づ くべきであろう。科学者は好奇心に駆動された研究 だけをしていれば、その応用はそれを所有する者が 責任をもって実施するという図式はもはやないし、 科学者は誤りを犯すかもしれない実施者と対峙して いるべきだという教訓も陳腐化した。人々という巨 大な存在にさらされつつ、科学者は専門性において 決定する責務を負うという、難しい状況の中で行動 すること、それが科学者の役割である。

このような状況を明示的に示すこと、そしてその 状況の中で、科学の社会的意義、科学の貢献と脅 威、科学知識への接近、仕組み、今後の科学研究の 方向、科学者の社会的地位など、そして一人の科学 者像について、その変革の方向を探る仕事が日本学 術会議に課せられている。

日本学術会議を定める法律に書かれている精神は 現在でも正しい。しかし、社会の変化に対応して、 その中に述べられる言葉の意味は様々に変化してい る。例えば、科学者の代表という言葉も例外ではな い。この言葉についての十分な検討なしには、日本 学術会議の行動は十分に意義づけられることはない し、また上述のような変革を主導する資格はない。

日本学術会議に抢ける自己改革の議論が真に有効 なものとなるために、私たちはこれからもより深い 議論を続ける必要があると考える。

吉川 弘之（よしかわ ひろゆき 1933年生） 第17期日本学術会議会長、放送大学学長 専門：基礎工学 